\title{
Do Our School Programmes Motivate Youth for Quality? - A Case from Slovenia
}

\author{
Milena Alič \\ Faculty of Economics, University of Ljubljana, Slovenia
}

Copyright $(2016$ by authors, all rights reserved. Authors agree that this article remains permanently open access under the terms of the Creative Commons Attribution License 4.0 International License

\begin{abstract}
Purpose: The paper highlights the issue of teaching for quality in our regular higher education programmes - just to have an insight into the situation and to find some improvement opportunities. Design/methodology/approach: Analysing a case from Slovenia our survey study focuses on quality management related courses at all the levels of education to see if they follow the realized importance of quality management in all spheres of life proved through literature review, manager claims and even through politician and journalist statements. It also analyses final student papers (undergraduate, graduate, master and doctoral theses) that could signal the students' interest in quality management. Findings: Slovenian education institutions do follow quality requirements regarding institution management. However, they offer only few specific quality management related courses. Additionally, less than 5\% of published final student papers in faculties offering quality management related programmes are related to quality matters. Research limitations/implications: The analysis of quality management related final student papers was limited only to the biggest Slovenian University in this preliminary research. It should be followed by some more detailed research on this topic giving stronger suggestions. Practical implications: School programmes should cover business needs regarding quality management knowledge and skills. Social implications: Teaching for quality through regular school programmes would be the most effective and systematic way to improve the culture of quality and responsibility in the society and to implement it in our organizations as well. Originality/value: The literature review showed some research on quality management of the higher education institutions. However, no research on quality topics in their offered courses and in student papers has been found.
\end{abstract}

Keywords Quality, Quality Management, Higher Education, Education Programmes, School Programmes

\section{Introduction}

Quality and innovation is an imperative for a successful modern business. This is often stressed by professional literature, businessmen, business agencies and associations, politicians and journalists [1]. On the other hand it is often publicly emphasised that youth education programmes (on all the levels) should support business needs $[2,3]$.

Business and education area should operate and develop hand in hand to bring up properly skilled and demanded professionals. In the area of quality management (QM) the aging of professional staff is noticed (regarding the age of active members of QM professional organizations (e.g. Slovenian Association for Quality and Excellence), auditors of certification bodies for ISO 9001. evaluators of National Business Excellence Award (PRSPO) ${ }^{1}$. It raised a question why young people rarely decide for such a profession. Is such a profession not demanded by business anymore? How important and interesting do our students find QM issues? Is there not enough motivation for such job orientation through education process?

In this research we will make only an insight into Slovenian primary, secondary and tertiary school programmes, searching for QM related programmes and approaches. The paper title shows the main research question: "Do our school programmes motivate youth for quality?" We expect that learning and living quality approaches in childhood and youth would be the least costly way to improve the culture of quality in the society and to implement it in our organizations as well. We'd like to open an issue of appropriate school programme offer and support to the business needs in the area of QM. Additionally, the research opens and could give some answers to our basic issue of proper youth motivation in taking quality related professions. It tries to give some answers to it, too.

1 Just to illustrate it the list of evaluators for the PRSPO as highly respected professionals for QM and business excellence (EFQM model) speaks for itself. In the year 2003 there were 42 professionals in that list, in the year 2010 their number rose up to 50 , but later on it fall to 29 in 2014 [70]. Additionally, only one professional in the list of 2014 was a new member in the last 5 years, other members shift from year to year, but at least two thirds of them were involved in the last 5 years, others even 10,15 years or more. 


\subsection{The Role of QM Standards and Models in Business}

One of indicators of importance of $\mathrm{QM}$ is a rise of $\mathrm{QM}$ standard implementations and certification (e.g. ISO 9001). Their number was rising on the global level all the years till 2011 and reached over 1.100 .000 certificates worldwide [4]. A slight decrease was noticed in the last year (on the global and European level), however in Slovenia the number of ISO 9001 certificates has been slightly falling since 2006 [5]. There has already been some research performed pointing to stagnation of growth of the number of ISO 9001 certificates in some areas due to lower marketing attractiveness QM system certification $[6,7]$. Some countries have already reached a market saturation level regarding the number of ISO 9001 certified organizations [6] or so-called "maturity level" of standardization and QM [8] where focuses have shifted from being certified to tools, techniques, and core values of QM. So certification loses its connotation and becomes less attractive for the remaining companies [9] and little or no certification growth is registered. Anyway, ISO 9001 is still the most widely used QM standard in the world. Additionally, the greatest benefits of the implemented QM approaches don't lie in their certification but rather in their internal positive effects on organizations' performance.

Extensive empirical research [10-13] proves positive effects of the ISO 9001 QMS implementation. Boiral [7] realized that $80 \%$ of the current studies measured significant benefits of such systems. According to the ISO survey in July 2011 the most important benefits of the ISO 9001 were improved customer satisfaction and standardized business processes [14]. Some research has shown a significant relationship between implementation of the QMS and the improved competitiveness and performance of organizations [7, 11, 15-17]. On the contrary, other research points to obstacles, side-effects and disadvantages of QM system implementations $[7,18-20]$ that are often related to low internal interest, management support, skills and understanding the QM philosophy and standard requirements [21, 22].

ISO 9001 is a general QM standard (not industry or subject specific). It introduces QM principles that are drivers for effectiveness and efficiency [71]. The majority of other specific management standards are focused on specific issues of specific industry or business field, but they are still based on the same QM principles and PDCA continuous improvement cycle. Many organizations develop their QM knowledge and systems by implementing one or more specific management standards, e.g. for environmental management system (MS) (ISO 14001, EMAS), energy MS (ISO 50001), information security MS (ISO 27001), occupational health and safety MS (BS OHSAS 18001), social responsibility MS (ISO 26000), automotive quality MS (ISO/TS 16949), food safety MS (HACCP, ISO 22000; IFS and BRC food standards), medical devices quality MS (ISO 13485) etc. Such systems may directly or indirectly contribute to the better operations, better management of business risks, better image and better company performance [17].

Beside the standards there are some other approaches (e.g. Six Sigma, 20 keys, business excellence models etc.) that help systematically develop quality and QM systems and result in some public recognition. Business excellence models such as EFQM are mostly implemented as an upgrade to the previously implemented QM standards. The most ambitious and quality committed organizations decide to take such a demanding and long-term but promising journey to excellence $[8,17]$.

\subsection{Identified Public Support and Promotion of QM Approaches}

Organizations implement QM approaches at their own will. Often the initiative comes from other organizations current or potential business partners. QM includes a set of directives, requirements and approaches to meet them - all as an aim to improve the quality of the product or service and satisfy the customer. So, QM was recognised as an important improvement driver in organizations and also on higher influencing levels of the society, such as enterprise associations, chambers and agencies and even on the government level, as well.

\subsubsection{Activities and documents on the national (Slovenian) level}

Some initiatives have been recognised in support to real sector:

- Ministry of economic development and technology promoted QM approaches in tourism in a special programme document [23]

- The Slovenian Chamber of Commerce announced actions to overcome the economic crisis (Agenda $48+$ ) in the year 2012 and upgraded them in the following year [24] intending to improve business performance and competitiveness of Slovenian enterprises and the economy as a whole. The quality issues were not explicitly emphasised, however providing the expected and standardized product and service quality and implementing system approach in management were implicitly included. Export orientation and innovation were (and still are) two of the most highlighted goals which can be easily attained when QM approaches (such as ISO 9001, $\mathrm{EFQM}, . .$.$) are implemented.$

- The targets and actions in the Slovenian industrial policy [25] can be more easily attained by implementing QM approaches although they aren't explicitly addressed.

- Additionally, Ministry of economic development and technology indirectly promoted QM approaches by developing "The Strategy of clever specialisation 2014-2020" in cooperation with The Slovenian Chamber of Commerce [26]. 
After intensive promotion and implementation of ISO 9001, EFQM and CAF in the public sector in the period 1995 to 2006 [27], the economic crisis and a decrease in funding these activities appeared. It resulted in giving up certification and decrease in the number of Slovenian business excellence prize applications. In the last few years new initiatives appeared to reactivate $\mathrm{QM}$ approaches and make public administration and other public services more effective and more efficient (less costly). Such initiatives were:

- Some public administration departments (such as Public payments administration of Republic Slovenia) set their quality policy and implement ISO 9001 [28].

- Some directives were given from the top of the public administration to make its services more customer oriented what is the basic QM directive [29].

- Ministry of Health developed a National strategy of quality and safety in health care (2010-2015) [30] where QM approaches have an important role.

- After some years of stagnation in implementation of QM systems in public sector, in 2012 an action (action no. 14) was announced by The Agency for government of capital investments of Republic Slovenia ("Agencija za upravljanje kapitalskih naložb Republike Slovenije - AUKN") to stimulate implementation of total QM based on the EFQM or CAF model in publicly funded organizations [31]. After closing of AUKN the action was transferred to its legal successor "Slovenska odškodninska družba SOD" (central ownership entity of Slovenia) as the action no. 11 [32].

- National Assembly - Board on Health discussed QM approaches in the perspective of overcoming the actual crisis in Health sector [33].

Additionally, in the last two years the discussions about quality matters entered the Slovenian Parliament and its bodies.

\subsubsection{Activities and documents on the European level}

The Europe Commission supports the QM approaches through its efforts for more innovation and better competitiveness. This is especially stressed in "Europe 2020: Europe's growth strategy", the "Integrated Industrial Policy", "European competition policy" and their key challenges [2, 34-36].

Important facts:

- A special role is given to research, development and innovation, knowledge and skills, environmental issues, competition etc. [35].

- More emphasis is given to European standardisation [34] including QM, product and services standards intending to gaining economic benefits from harmonisation and economies of scale at all levels (international, European and national). Standards should not create an additional burden, e.g. to SMEs.
Instead, they should lead to efficiency gains and act as an incentive for innovation. The ultimate aim should be convergence of standards at world level.

- Europe's (co)funding is provided for the development of the above mentioned strategic areas. QM is not directly specified among them. However, well implemented QM approaches are often needed to attain the specified objectives and get funding from EU calls and tenders.

- The Association of European Chambers of Commerce and Industry - EUROCHAMBRES [37] pushes for a business-driven approach to $\mathrm{EU}$ research and innovation policy, highlighting in particular the pivotal link between entrepreneurship and innovation following the EU prospective Horizont 2020. Therefore, policy makers have to find new and better ways to involve SMEs in the innovation process, which must no longer be perceived as purely research based. By facilitating better SMEs participation better support and motivation for implementing QM approaches is given as well.

- $\quad$ All European organisations, both in the public and private sectors, are facing new challenges. The increasing pressure to compete on a global stage with limited resources means we all have to work together to secure our future prosperity, and that of generations to come. The EFQM Excellence Model provides a framework that encourages the cooperation, collaboration and innovation that we will need to ensure this goal is achieved." (Herman van Rompuy, President of the European Council) [38].

\subsection{Identified Needs of QM Professionals}

We can't measure the direct impact of above mentioned public emphases on quality. The bad economic situation in many organizations and the decreased demand on certifying QM systems $[6,8]$ don't show there have been evidential positive effects already. Especially in the public sector and in organizations having financial problems the cost-cutting influenced the QM trainings and projects. Although the number of maintained and certified QM systems has fallen, the need for QM properly trained people that could help organizations to operate better has probably even risen. However, there is no available evidence about it.

The need of school programmes giving QM knowledge and skills is evident from:

- the predictions of QM scientist [39-40]

- the directly or indirectly recognised needs of enterprises for having or employing QM skilled people $[7,13,21,41]$

- the directly or indirectly recognised needs in the national economic policy and its documents:

- In the Slovenian industrial policy [25] the action no. 9 addresses adapting educational and training 
systems to the needs of the business. Enterprises need competent and skilled workers as the output of our schools.

- the directly or indirectly recognised needs in the European economic policy and its documents:

- The needs of SMEs are given high priority. SMEs represent the core of industry. About $95 \%$ of all European companies are SMEs [42]. Adapting educational and training systems to the needs of the business is one of strong directives in the documents of European Commission such as "Europe 2020: Europe's growth strategy" and "An Agenda for new skills and jobs" [2,3].

- The number of QM professionals differs among European countries. "With its 502 experts per million inhabitants, Slovenia is among the countries with highest degree of participation (data for 2008). In some countries, this figure attains 430 experts per million inhabitants, 350 in big and rich countries, and only about 130 in big new Member States of the EU" [42].

\section{Methodology}

The research is based on review of literature regarding QM approaches, their use and benefits and on searching for publicly available information and data showing actual business interest in QM approaches and their needs of QM skilled people. The used research method was analysis and synthesis of the findings.

Our study is just a preliminary study testing the QM orientation, motivation and support in Slovenian regular tertiary school programmes with the intent of highlighting the issue of students' motivation for studying QM matters. Publicly available documents and data of Ministry of education, science and sport ("Ministrstvo za izobraževanje, znanost in sport" - MIZS) and NAKVIS were analysed.

We expected that schools can transfer QM knowledge and praxes in three ways:

a) by practicing it in everyday praxes of the staff and the pupils / students (It could be a result of a well-working QM in the school and properly skilled and quality committed staff). This was examined in the first step of the research, the results are in chapters 3.1 to 3.3 .

b) by offering proper $\mathrm{QM}$ related programmes and topics and thus delivering theoretical knowledge about QM basics, issues and solutions. This was the subject of the second step of the research, the results are in chapter 3.4.

c) by motivating and encouraging students to address QM issues in their research. The results of these activities can be recognized in student final papers. The analysis of the topics of the student final papers was the focus of the third step of our research, the results are in chapter 3.5 .
In the first step we examined the required and expected level of QM system in schools at each of the three levels of education. On the other hand we investigated the realized QM implementation and its maturity, as follows:

- At first we gathered the statistical data from SURS [45] about the share of the population involved at each of the three levels of education (the results are in chapter 3.1). This data was important for the interpretation of the results of the second step of this research.

- Next to it we tried to find elements of $\mathrm{QM}$ in educational regulation, national programmes and regular tertiary educational programmes by searching the documents on the web pages of the public bodies governing and controlling them (MIZŠ, NAKVIS). As the result we prepared a descriptive analysis (chapter 3.2).

- Additionally, we searched on the internet for the schools exceeding the minimum QM requirements what could be proven by the gained proper quality related certificates. We searched also for any information about institutions that are on the way to implement a more comprehensive QM system but hadn't gained any formal proofs yet. The analysis is only descriptive (chapter 3.3).

In the second step we searched for QM related educational content in school programmes from the list of official educational courses published by MIZS [43]. We assumed that it could be recognised from the title of the programmes if it is related to QM topics. Therefore, we searched for the school programmes / courses having "quality" or quality related expressions in their titles. We didn't analyse the programmes in detail regarding implicitly included or detailed QM related contents and approaches. The comparison between the QM related and all the programmes was prepared upon grouping the programmes into 3 main groups (one for each level of education). In some of these groups subgroups were introduced according the Slovenian education system structure (MIZŠ) [43]. The number of the found $\mathrm{QM}$ related programmes was compared to the total number of school programmes in each group or subgroup (chapter 3.4). If there were only a few QM related programmes found they were listed (by the name of the programme) instead of just presenting the number of them.

In the third step we searched for final student papers (undergraduate, graduate, specialist, master and doctoral theses) of the faculties offering QM related programmes. We assumed that the students' motivation for QM or their professional interests in this area would be recognized through the choice of the topics for their final student papers. So we analysed how many of the published student papers addressed the QM issues. The analysis was limited to only one (the biggest) Slovenian university - University of Ljubljana and its two faculties offering QM courses (The Faculty of Economics, The Faculty of Mechanical Engineering) using publicly available data through 
electronic library service COBISS/OPAC [44]. We searched for the student papers (undergraduate, graduate, master and doctoral theses) in the period 2006 - 2013 having "quality" or quality related expressions in their titles or key words. The number of papers in each selection group was used for calculating the share of QM related final papers among all the final papers of the chosen faculty in the chosen period. This way the shares of QM related papers were calculated for each of 4 groups of final papers (from graduate to doctoral theses) in each year in the analysed period. Descriptive statistics is used to present the average shares and their standard deviation over the years. The results are shown in a table form and compared to the total number of students finishing the addressed programmes (see chapter 3.5).

\section{Findings}

\subsection{The Population Involved in Formal Education Programmes}

Similarly as other EU countries in Slovenia most of the generations of young people are involved not only on primary but also on higher levels of education. For instance, in Slovenia in the year 2011/12 89, 1\% of young people (19 to 24 years old) passed at least middle level education programs. Additionally, in this period almost $50 \%$ of the whole population in this age group continued their education on a higher level (on a high school or university). However, this percentage is still expected to rise. According to the Slovenian National program the goal for the period 2011 to 2020 is $75 \%$ of young people to study on a higher level [45]. Therefore the formal education programmes have an important role on upbringing and education of young generations.

\subsection{Regulated QM Requirements in Education}

It is in the national and international interest that educational institutions offer appropriate level of quality of the educational process and programmes. Regulatory requirements have been set on the national and European level to assure it. The national regulation is harmonized with the European one.

Therefore educational institutions implement the adapted form of a quality assurance or QM system. The pupils and students shall benefit from the implemented QM activities, such as environment orientation, planning, provision of appropriate resources, involvement of all stakeholders (including pupils, their parents and students) in management bodies of the institutions, measuring the stakeholders' satisfaction, regular result measurement and self-assessments as the basis for improvement actions. Pupils and students shall get some experiences in a particular QM activity (such as satisfaction survey) if they are involved. Actually, it doesn't happen that all the pupils and students are involved in such activities and it is probably not the intent to practically teach them this way about $\mathrm{QM}$ issues and approaches. Therefore, the benefits of implemented QM systems are mostly overall better teaching process contributing to better learning of the topics covered by educational programmes. So, QM topics should be included in the educational programmes in order to be learned in schools.

\subsubsection{Required Quality Assurance in Primary Education}

In the regulation (Act on the primary schools and the related documents) [43] there is no explicit requirement on QM in primary schools. However, some QM elements can be found in the act but QM requirements and responsibilities are not explicitly given.

\subsubsection{Required Quality Assurance in Secondary Education}

In the secondary schools area there are two groups of schools: general secondary schools (gymnasiums) and vocational secondary schools of different levels. There is still no explicit QM requirement in regulation for gymnasiums (Act on gymnasiums), however such requirements are set for vocational and professional secondary (lower, middle and higher level) schools [43]. On the middle level just a "Quality assurance commission" and a set of QM activities are required (Act on vocational and professional secondary education) [43], on the higher level external evaluation and accreditation (as described in the next paragraph) is required as well [46].

\subsubsection{Required quality assurance in tertiary (higher) education}

Regulatory requirements specify external evaluation and accreditation criteria and "The Slovenian Quality Assurance Agency for Higher Education - SQAA" (Agency) as the accreditation body. Educational institutions and programmes should be granted accreditations upon meeting minimum quality assurance criteria, set by national legislation [43]. The criteria comply with the quality assurance standards and guidelines that apply in the European Higher Education Area [47].

Required accreditation procedure and evaluations by the Agency in higher education institutions as a recognition of meeting quality assurance criteria:

- The accreditation procedure for higher education institution and programmes as well as the evaluation process as a part of it are determined in the Criteria for the accreditation and external evaluation of higher education institutions and study programmes (Criteria) [46]. In our paper we focus on criteria for accreditation and evaluation of institutions. The procedure is described in articles 3 (definitions), 6 to 15 (initial accreditation) and 22 to 35 (re-accreditation).

- Areas which are the subject of higher education institution assessment (Articles 8 and 26) in initial accreditation and re-accreditation are the following:

1. integration with the environment (with intent to 
cover staff needs of the business and social environment and making students employable);

2. functioning of the higher education institution (planning, achieved results and management of the institution);

3. human resources (providing appropriate study programmes, providing needed and competent teaching and research staff);

4. students (students' satisfaction, study interests, enrolment, results and after-study employments, involvement in the institution's processes and participation in institution's management bodies);

5. material conditions (premises and equipment, their suitability for students with special needs, funding, library and information services);

6. quality assurance (including regular self-assessments of the institution), innovation and development orientation.

\subsection{Voluntary Additional Certified QM Approaches in Education Institutions}

Educational institutions want to attract new potential pupils or students. Enough enrolled pupils/students enable educational institutions to perform and finance the educational programmes. One important element to attract new pupils/students is the quality of the educational process and programmes. Especially on the higher levels of education students seek for the knowledge and skills that enable them to get a job after finishing the programme or study. Institutions compete for the pupils/students, so exceeding the required minimum level of quality can be one of the drivers for survival and successful development of the institutions and their programmes. Therefore some of them already implement quality tools and systems which would help them with it and give them some recognisable external signal of quality.

\subsubsection{Voluntary additional quality assurance in primary education (standards and certifications)}

Some primary schools (e.g. OŠ II Murska Sobota) implemented and certified ISO 9001 [48], some of them (e.g. OŠ Šentvid, OŠ Trbovlje) implemented locally developed QM scheme for educational organizations Quality for future of education - KzP ("Kakovost za prihodnost vzgoje in izobraževnja") [49]. This scheme, established by a national certification body SIQ [50], helped changing quality culture in these organizations.

\subsubsection{Voluntary additional quality assurance in secondary education (standards and certifications)}

There were some but rare secondary schools implementing and certifying ISO 9001 (e.g. Visoka šola za zdravstveno nego Jesenice, Šolski center Škofja Loka) or KzP (e.g. Gimnazija Franceta Prešerna) [49].

\subsubsection{Voluntary additional quality assurance in tertiary} (higher) education (standards and certifications)
Recognisable external signals of quality of some institutions are their attained international accreditations (like EQUIS, AACSB, TedQual, etc.) [51]. Some institutions implement the international quality management standard ISO 9001 [52-54] or business excellence model EFQM [55]. Some quality agencies (e.g. The centre of accreditation and quality assurance of Swiss University) already realised that some concepts from the ISO 9001 and the EFQM may be transferable and applied to education for both systems call for strong leadership, broad stakeholder involvement and the use of success indicators [56].

There are also special IT applications developed and available, such as "Teaching capability maturity model" (T-CMM) [57] supporting QM of a teacher's individual teaching process and thus helping to improve the quality of the teaching process.

\subsection{Quality Related Topics and Courses in the Regular School Programmes}

Quality issues and approaches are being recognized as important, leading to better competitiveness on the organizations', national and international levels. Therefore, some basic knowledge of PDCA continuous improvement cycle and some basic quality related values and skill need to be built-in in everyone's thinking, especially in thinking of high educated people who will probably lead other people and manage business in the future. These QM principles are really some basic management principles that could be fostered through education process starting at its basic levels.

The found valid official educational programmes in Slovenia and their courses [58-62] that obviously cover some of QM topics are listed in the next paragraphs as results of our research.

\subsubsection{Quality related topics and courses in primary schools}

In the primary schools there are no explicitly mentioned QM topics mentioned in the primary school official educational programmes.

However, there are some written programme guidelines for teaching staff and class communities of primary and secondary schools [58] where some QM guidelines (similar to the ones of ISO 9000) are suggested to be considered by teaching. On the other hand, no explicit emphasis on teaching for improvement and innovation is recognized in these guidelines.

So, in the primary schools some basic values important in QM approaches and sustainable development may be given and discussed only within the obligatory courses (e.g. social and technical courses). Additionally, there are some possibilities in the primary school extended program and interest activities (language, technical, IT, sport, arts courses). Basically, they aren't QM oriented but can include some of its principles (probably it is up to school and the teachers' affinity to use of such principles).

\subsubsection{Quality related topics and courses in secondary schools}


The general secondary schools (gymnasiums) continue sharing general knowledge at more comprehensive level. There are no special QM related courses in this group of schools. However, there are some rare other courses that are related to QM or may cover some of these topics. So, there exists only one obligatory course "Entrepreneurship" on the Economic gymnasium and two optional courses "Mechanical engineering " on the Technical gymnasium [59]. There are still two obligatory elective contents that may be QM related: "Entrepreneurship" on the Economic and Technical gymnasiums and "Project work" on the Economic gymnasium.

QM principles and approaches are at most represented in the educational programmes of vocational secondary (lower, middle and higher level) schools [60-61].

There are no special QM related courses in lower level vocational education programmes [62] offering practical oriented knowledge catalogues for 6 vocational qualifications.

The middle level vocational programmes include knowledge catalogues for 42 vocational qualifications. There are no special QM related courses in these programmes [62] either, however some of the QM principles and topics may be included in their general business oriented courses - on processes $(7$ courses in 5 qualifications' knowledge catalogues) and organization ( 1 course in 8 qualifications' knowledge catalogues). All such process or organization oriented contents are included in educational programmes for manufacturing vocations (especially in metal, automotive and electro industries).

The middle level professional programmes include knowledge catalogues for 38 professional qualifications. Special QM related courses exist (5 QM course in 5 qualifications' knowledge catalogues $=1 \mathrm{QM}$ course per each professional qualification) [62]. There are also business oriented courses - on processes ( 8 courses in 8 qualifications' knowledge catalogues) and organization (7 courses in 7 qualifications' knowledge catalogues). Altogether there are 15 ones (a few manufacturing oriented ones, the most of them service oriented) from 38 professions that have special $\mathrm{QM}$, process or organization oriented courses in their educational programmes.

The higher level professional programmes include knowledge catalogues for 31 professional qualifications. Special QM related courses are more often offered (6 QM courses exist in 6 qualifications' knowledge catalogues $=1$ QM course per each professional qualification) [62]. There are also more business oriented courses - on processes (10 courses in 6 qualifications' knowledge catalogues) and organization (18 courses in 12 qualifications' knowledge catalogues). Altogether there are 17 (mostly service oriented) ones from 38 professions that have special $\mathrm{QM}$, process or organization oriented courses in their educational programmes.

\footnotetext{
3.4.3. Quality related topics and courses in tertiary (higher) schools
}

In the tertiary schools there are 769 study programmes in public universities and high schools and 168 ones in private institutions in Slovenia in 2014 [61]. The enhanced QM programmes and courses are offered at faculties on all three levels of study (the professional, university, master and the doctoral degree) [61]. In Slovenia the only specialised QM study on all these levels is offered by only one faculty $-\mathrm{a}$ private Faculty of organization studies Novo mesto ("Fakulteta za organizacijske študije" - FOŠ).

On other private high schools and universities and on all three public Slovenian universities no complete QM programmes or specialisations exist. There are a few study programmes on some faculties covering some of the QM topics in one or two obligatory or optional courses / learning units. Such programmes are:

- "Poslovodenje in organizacija" (Management and organization) at the Faculty of economics of University of Ljubljana;

- "Strojništvo" (Mechanical Engineering) at the Faculty of mechanical engineering of University of Ljubljana;

- "Ekonomske in poslovne vede" (Economic and business science) at the Faculty of Economics and Business of University of Maribor;

- "Organizacija in management poslovnih in delovnih sistemov" (Organization and management of business and work processes) and "Organizacija in management informacijskih sistemov" (Organization and management of information systems) at the Faculty of organizational sciences of University of Maribor;

- "Vodenje in kakovost v izobraževanju" (Leadership and quality in education), "Ekonomija v sodobni družbi" (Economy in modern society) and "Vseživljenjsko učenje: management razvoja kadrov" (Whole-life learning: management of human resource development) at a private International school for social and business studies Celje ("Mednarodna fakulteta za družbene in poslovne študije").

Table 1 shows the number of enrolled students in the period 2006/07 - 2012/13 in the University of Ljubljana and their recognized faculties offering QM related courses in their study programmes (Faculty of economics; Faculty of mechanical engineering). Table 2 shows the number of students finishing their study on this university and the chosen faculties in this period. Additionally, data on student enrolment and the study completion is shown for some years (whether such information was publicly available).

As we may see from both tables there were 183 students enrolled in the QM related programme "Poslovodenje in organizacija" (Management and organization) at the Faculty of economics of University of Ljubljana in the year 2012/13. This is about $3.8 \%$ of all the 4861 students enrolled in this institution. Additionally, the data for the years 2006 and 2007 show there were 120 students finishing the mentioned 
QM related programme in the year $2006(=7.5 \%$ of all the 1595 graduates) and 129 students in the year 2007 (=8.1\% of all the 1587 graduates). The detailed information on enrolment in this programme and their graduates was not publicly available.
The Faculty of mechanical engineering of University of Ljubljana offers QM related courses on all the levels of their study programme "Mechanical engineering" (see Table 1 and 2). So, all the students can get some of this knowledge through the study.

Table 1. Number of enrolled students in Ljubljana University and its chosen members in the period 2006/07 to 2012/13

\begin{tabular}{|c|c|c|c|c|c|c|c|c|}
\hline \multirow[b]{3}{*}{$\begin{array}{l}\text { University nember/ } \\
\text { programme degree }\end{array}$} & \multicolumn{8}{|c|}{ Number of enrolled students } \\
\hline & \multicolumn{7}{|c|}{ Year } & \multirow{2}{*}{$\begin{array}{l}\text { QU related } \\
\text { programmes } \\
\text { in } 2012 / 13\end{array}$} \\
\hline & $2006 / 07$ & $2007 / 08$ & $2008 / 09$ & $2009 / 10$ & $2010 / 11$ & $2011 / 12$ & $2012 / 13$ & \\
\hline \multicolumn{9}{|l|}{ Faculty of Economics } \\
\hline $1^{\text {st }}$ degree & 2327 & 3137 & 3810 & 3762 & 4310 & 3796 & 2914 & \\
\hline $2^{\text {nd }}$ degree & 900 & 958 & 874 & 2002 & 1899 & 2370 & 1879 & 183 \\
\hline $3^{\text {rd }}$ degree & 0 & 0 & 23 & 57 & 88 & 108 & 68 & \\
\hline "old" undergraduate & 3565 & 649 & 450 & 40 & 61 & 13 & & \\
\hline "old" postgraduate & 40 & 284 & 891 & 48 & 15 & 12 & & \\
\hline Total & 6832 & 5028 & 6048 & 5909 & 6373 & 6299 & 4861 & 183 \\
\hline \multicolumn{9}{|c|}{ Faculty of Mechanical Engineering } \\
\hline $1^{\text {st }}$ degree & 0 & 0 & 324 & 1165 & 1420 & 1528 & 1565 & 1565 \\
\hline $2^{\text {nd }}$ degree & 0 & 0 & 0 & 0 & 0 & 291 & 335 & 335 \\
\hline $3^{\text {rd }}$ degree & 0 & 0 & 0 & 60 & 96 & 116 & 135 & 135 \\
\hline "old" undergraduate & 2041 & 1881 & 1864 & 1188 & 1181 & 1073 & 251 & 251 \\
\hline "old" postgraduate & 100 & 113 & 129 & 74 & 42 & 19 & & \\
\hline Total & 2141 & 1994 & 2317 & 2487 & 2739 & 3027 & 2286 & 2286 \\
\hline \multicolumn{9}{|l|}{ University of Ljubljana } \\
\hline $1^{\text {st }}$ degree & 7378 & 10221 & 14594 & 22565 & 26907 & 28845 & 26843 & 1565 \\
\hline UN (university level) & 4526 & 6726 & 9644 & 14848 & 18231 & 19924 & 19063 & 1565 \\
\hline VS (higher professional / ba & 2852 & 3495 & 4950 & 7717 & 8676 & 8921 & 7780 & \\
\hline uniform master's study & & 221 & 760 & 1577 & 2273 & 2921 & 3358 & \\
\hline uniform master's study & & 221 & 760 & 1577 & 2273 & 2921 & 3358 & \\
\hline $2^{\text {nd }}$ degree & 1091 & 1116 & 1153 & 3345 & 4322 & 6056 & 6765 & 518 \\
\hline master & 1091 & 1116 & 1153 & 3345 & 4322 & 6056 & 6765 & 518 \\
\hline $3^{\text {rd }}$ degree & 5 & 178 & 344 & 1275 & 1920 & 2210 & 451 & 135 \\
\hline doctor & 5 & 178 & 344 & 1275 & 1920 & 2210 & 451 & 135 \\
\hline "old" undergraduate & 50279 & 45875 & 38382 & 25622 & 17348 & 12136 & 5685 & 251 \\
\hline UN (university level) & 33883 & 31952 & 27839 & 19136 & 13741 & 10313 & 5496 & 251 \\
\hline VS (higher professional / ba & 16396 & 13923 & 10543 & 6486 & 3607 & 1823 & 189 & \\
\hline "old" postgraduate & 3769 & 3688 & 4386 & 2255 & 839 & 467 & 12 & \\
\hline doctor & 855 & 882 & 918 & 951 & 777 & 399 & 12 & \\
\hline master & 2724 & 2595 & 3277 & 1240 & 62 & 68 & & \\
\hline specalist & 190 & 211 & 191 & 64 & & & & \\
\hline Total & 62522 & 61299 & 59618.5 & 56638 & 53608.5 & 52634 & 43113 & 2469 \\
\hline
\end{tabular}


Table 2. Number of graduates at Ljubljana University and its chosen members in the period 2006 to 2012

\begin{tabular}{|c|c|c|c|c|c|c|c|c|c|}
\hline \multirow{3}{*}{$\begin{array}{l}\text { University menber/ } \\
\text { programe degree }\end{array}$} & \multicolumn{9}{|c|}{ Number of graduates (students finishing the study) } \\
\hline & \multicolumn{7}{|c|}{ Year } & \multirow{2}{*}{$\begin{array}{l}\text { OY related } \\
\text { procrames } \\
2007 \\
\end{array}$} & \multirow{2}{*}{\begin{tabular}{|l} 
CV related \\
prozrames \\
2008 \\
\end{tabular}} \\
\hline & 2006 & 2007 & 2000 & 2009 & 2010 & 2011 & 2012 & & \\
\hline \multicolumn{10}{|l|}{ Faculty of Economics } \\
\hline $1^{\text {tt }}$ degree & & & 154 & 403 & 570 & 678 & 742 & & \\
\hline \begin{tabular}{|l|l} 
to (univerzity leve 1 ) \\
\end{tabular} & & & 138 & 316 & 409 & 505 & 550 & & \\
\hline \multicolumn{2}{|c|}{\begin{tabular}{|l} 
VS (hizher profezzions1 / bachelor) \\
\end{tabular}} & & 16 & 87 & 161 & 179 & 192 & & \\
\hline \begin{tabular}{|l|l|}
$2^{\text {nd }}$ degree \\
\end{tabular} & & 65 & 170 & 162 & 160 & 185 & 209 & 13 & 95 \\
\hline \begin{tabular}{|l|} 
master \\
\end{tabular} & & 65 & 178 & 162 & 160 & 185 & 209 & 13 & 95 \\
\hline \multicolumn{10}{|l|}{$3^{\text {rd }}$ degree } \\
\hline \multicolumn{10}{|l|}{\begin{tabular}{|l} 
doctor \\
\end{tabular}} \\
\hline "old" undereraduate & 1211 & 1201 & 1051 & 239 & 580 & 300 & 181 & & \\
\hline DN (univerzity leve1) & 528 & 604 & 563 & 445 & 350 & 188 & 113 & & \\
\hline \begin{tabular}{|l|l} 
VS (higher profezsions1 / bact \\
\end{tabular} & 603 & 597 & 400 & 394 & 230 & 120 & 68 & & \\
\hline "old" posteraduate & 417 & 329 & 204 & 335 & 190 & 159 & 137 & 107 & 34 \\
\hline \begin{tabular}{|l|} 
doctor \\
\end{tabular} & 20 & 22 & 24 & 22 & 19 & 11 & 17 & & 11 \\
\hline master & 279 & 228 & 132 & 283 & 140 & 130 & 117 & 107 & 23 \\
\hline specalizt & 110 & 79 & 48 & 30 & 23 & 10 & 3 & & \\
\hline Iotal & 1628 & 1595 & 1537 & 1739 & 1500 & 13390 & 1355. & 120 & 129 \\
\hline \multicolumn{10}{|l|}{ Faculty of Yechanical Incineerine } \\
\hline $1^{\text {tt }}$ degree & & & & & & 96 & 125 & & \\
\hline \begin{tabular}{|l|} 
TN (univerzity leve1) \\
\end{tabular} & & & & & & 96 & 114 & & \\
\hline \multicolumn{10}{|c|}{\begin{tabular}{|l} 
VS (hizher profezzions1 / bachelor) \\
\end{tabular}} \\
\hline \multicolumn{10}{|c|}{\begin{tabular}{|l|l|}
$2^{\text {nd }}$ degree & \\
\end{tabular}} \\
\hline \multicolumn{10}{|l|}{ master } \\
\hline \multicolumn{10}{|l|}{$3^{\text {rd }}$ degree } \\
\hline \multicolumn{10}{|l|}{ doctor } \\
\hline \begin{tabular}{|l|l|} 
"old" undereraduate \\
\end{tabular} & 150 & 212 & 209 & 212 & 233 & 221 & 259 & 212 & 209 \\
\hline \begin{tabular}{|l|} 
LN (univereity 1eve 1 ) \\
\end{tabular} & 49 & 79 & 86 & 75 & 107 & 71 & 128 & 73 & 86 \\
\hline VS (higher profezzions1 / bact & 109 & 139 & 123 & 137 & 126 & 150 & 131 & 139 & 123 \\
\hline \begin{tabular}{|l|l|} 
"old" posteraduate \\
\end{tabular} & 22 & 16 & 30 & 29 & 38 & 31 & 25 & 16 & 30 \\
\hline \begin{tabular}{|l|} 
doctor \\
\end{tabular} & 13 & 6 & 13 & 17 & 23 & 16 & 15 & 6 & 13 \\
\hline master & 9 & 10 & 10 & 8 & 7 & 10 & 8 & 10 & 10 \\
\hline specaliat & & & 7 & 4 & 8 & 5 & 2 & & 7 \\
\hline Total & 180 & 2238 & 239 & 241 & 271 & 348 & 416 & 2238 & 239 \\
\hline \multicolumn{10}{|l|}{ University of Ljub1jana } \\
\hline $1^{\text {th }}$ degree & & 30 & 170 & 1126 & 1650 & 2372 & 3502 & & \\
\hline \begin{tabular}{|l|} 
DN (univerzity leve1) \\
\end{tabular} & & 37 & 145 & 759 & 1283 & 1772 & 2703 & & \\
\hline \multicolumn{2}{|c|}{\begin{tabular}{|l|l|l} 
VS (hizher profezsions1 / bachelor) \\
\end{tabular}} & 1 & 25 & 367 & 375 & 600 & 879 & & \\
\hline \begin{tabular}{|l|l|} 
uniforn master' s study \\
\end{tabular} & & 67 & 296 & 222 & 250 & 347 & 598 & 13 & 95 \\
\hline uniforn naster' z study & & 67 & 195 & 180 & 196 & 293 & 559 & 13 & 95 \\
\hline $2^{\text {nd }}$ degree & & & 41 & 42 & 54 & 54 & 39 & & \\
\hline naster & & & 41 & 42 & 54 & 54 & 39 & & \\
\hline $3^{\text {rd }}$ degree & & & & 1 & 1 & 40 & 57 & & \\
\hline \begin{tabular}{|l|} 
doctor \\
\end{tabular} & & & & 1 & 1 & 40 & 57 & & \\
\hline "old" under craduate & 7851 & 7403 & 7070 & 6467 & 6650 & 5384 & 4777 & 212 & 209 \\
\hline \begin{tabular}{|l|} 
LN (university leve1) \\
\end{tabular} & 4830 & 4598 & 4535 & 4403 & 4626 & 9052 & 3515 & 73 & 36 \\
\hline VS (higher profezzions1 / bach & 3013 & 2805 & 2535 & 2064 & 2032 & 1532 & 1262 & 139 & 123 \\
\hline \begin{tabular}{|l|} 
"old" posteraduate \\
\end{tabular} & 1209 & 1201 & 1069 & 1174 & 1053 & 920 & 797 & 123 & 64 \\
\hline \begin{tabular}{|l|} 
doctor \\
\end{tabular} & 327 & 347 & 357 & 373 & 387 & 353 & 348 & 6 & 24 \\
\hline master & 728 & 661 & 577 & 681 & 551 & 522 & 409 & 117 & 33 \\
\hline \begin{tabular}{|l|} 
specalist \\
\end{tabular} & 234 & 193 & 135 & 120 & 115 & 45 & 40 & & 7 \\
\hline Total & 9140 & 8709 & 8545 & 8990 & 9620 & 9063 & 9811 & 348 & 368 \\
\hline A11 hicher education institution & n Slove & aia & & & & & & & \\
\hline Iotal & 24784 & 23790 & 23472 & 25094 & 27684 & 26760 & 23406 & & \\
\hline
\end{tabular}




\subsection{Published QM Related Student Final Papers at Faculties Offering QM Courses}

\subsubsection{The case of the Faculty of Economics}

Table 3 shows that in the period 2006 to 2013 the share of QM related student final papers differs among the study programme levels (from the average annual percentage of $2.1 \%$ at the first (university) degree up to $6,3 \%$ at the third (doctoral) degree. These papers study mostly QM systems and models (such as ISO 9001, HACCP, ISO 27001, 20 keys, EFQM etc.) implementation, certification, effects and impact on business, their special requirements (such as documentation, process management, audits, continuous improvement etc.).

Compared to the share of the graduates of the QM related programme "Poslovodenje in organizacija" to all the graduates at the master level in the years 2006 and 2007, $41 \%$ of the master level graduates finished this programme in the year 2006 (=120 of all the 293 students) and 33,8\% in the year 2007 (=129 of all the 382 students). In these two years the percentage of the published QM related master theses was $5 \%(0.5 \%$ over the average of the whole period $)$. It means that only up to $15 \%$ of the students taking this QM related programme addressed QM issues in their final papers.

Additionally Table 3 shows that there were some QM related student final papers in other programmes that didn't offer special QM related courses (e.g. on the first and on the third study level). Nevertheless, in the analysed period the average share of QM related published final papers in the institution was low (only 3.3\%). It doesn't show strong interest and motivation among students in studying QM related issues.

\subsubsection{The case of the Faculty of Mechanical Engineering}

Table 4 shows that in the period 2006 to 2013 the share of QM related student final papers differs among the study programme levels (from the average annual percentage of $1.5 \%$ at the third (university) degree up to $13.7 \%$ at the specialist programme of the second degree. In this institution QM courses are offered on all the levels as obligatory or elective ones. So all the students hear and learn at least something about quality and QM. The contents are probably more technically oriented. This is recognised from the published final student papers. Some of them address technical quality (product and technology characteristics), others address QM issues (as described in the case of the Faculty of economics). In Table 4 the both groups of quality related papers are presented separately (in two columns, labelled as "technical Q related" and "QM related" papers). Our analysis is focused especially in motivation for QM issues among students, so only QM related papers were taken in further calculation of the share of QM related papers.

In the analysed period (according to the available data) the average percentage of the published QM related papers in the institution as a whole was $5 \%$. When considering also technical quality papers, the average percentage would be much higher $(7.8 \%)$. It means that $5 \%$ of the students of the Faculty of Mechanical Engineering addressed QM issues in their final papers and additional $2.8 \%$ of the students addressed other technical quality related issues.

Table 3. Number of published QM related student final papers (theses) at the Faculty of economics in the period 2006 to 2013

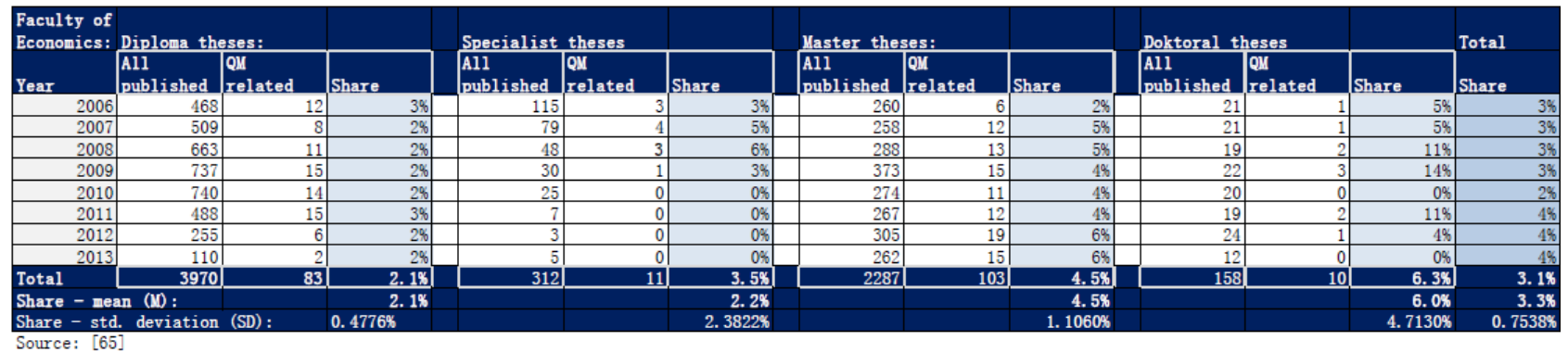

Table 4. Number of published QM related student final papers (theses) at the Faculty of mechanical engineering in the period 2006 to 2013

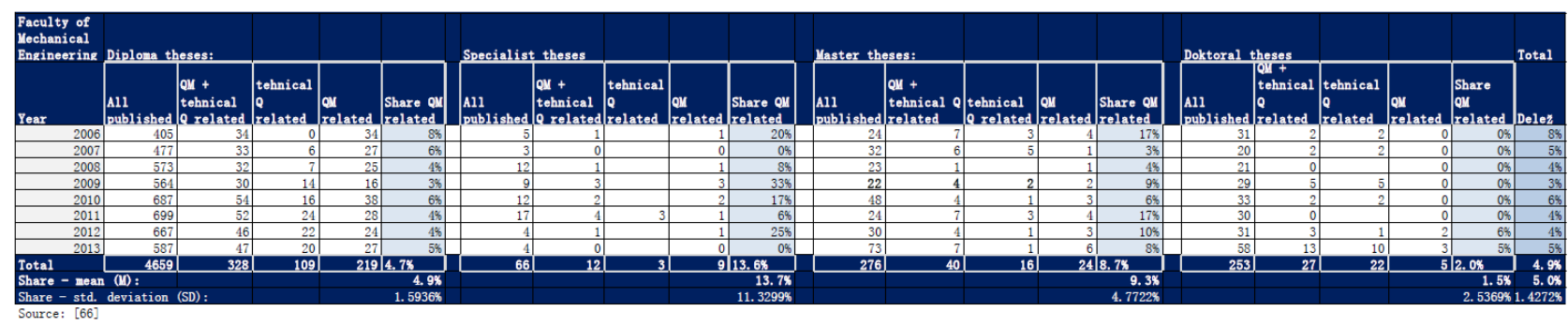




\section{Discussion}

The primary schools are established to give young people the basic general knowledge for further education and life. It is also not explicitly required by the legislation [43, 58]. So no detailed QM knowledge is expected.

In the secondary schools area there are two groups of schools: general secondary schools (gymnasiums) and vocational secondary schools of different levels. The general secondary schools (gymnasiums) have a similar mission as the primary schools - giving the general knowledge at more comprehensive level. There is still no explicit QM requirement in regulation for gymnasiums [43, 46, 59].

The secondary vocational schools are very practical oriented. These institutions should develop quality assurance procedures according to the regulation [43, 46], regulated publicly available curriculums and professional qualification knowledge catalogues are set for this type of education [60-62]. Following the regulation they also offer on the middle and higher level some QM related courses and contents. Special courses are still rare. More often organization and process management knowledge or just learning specific profession related processes is a frame for getting known with some QM approaches.

In Slovenia more than $70 \%$ of the young people [67] that were finishing one of the secondary schools in that year or almost $50 \%$ of the whole population in this age group (19 to 24 years old) intended to continue their study on a higher level (on a high school or university). Other $30 \%$ of them would probably begin working (take a job) at the level of knowledge they had got by the end of their secondary level of education (also in the field of QM). According to the Slovenian National program the goal for the period 2011 to 2020 is $75 \%$ of young people to study on a higher level [45]. However, this percentage is still expected to rise.

The majority of the population $(70 \%$ of the young people finishing secondary schools) still has an opportunity to upgrade their QM knowledge at the faculty. However, the choice of study programmes that cover QM topics is really narrow as realised through our analysis. At the secondary education level there might be some QM related topics included in some general or profession specific courses. The names of the courses in the curriculums and professional qualification knowledge catalogues showed their linkage with general organization, project and process management topics or profession specific quality issues. No courses dedicated to any specific QM approach (tool, QM standard, industry tailored application) were recognized by analysing the names of the courses. We can conclude that QM related topics were evidently embedded into less than a half of all the middle and higher level professional programmes qualification profiles. It is supposed that QM matters are in some part still delivered through different general and specific courses (not recognized in this research). A detailed and more comprehensive analysis of all the syllabuses of the delivered courses would be needed to recognize it.
In Slovenia the only specialised QM study at the all three tertiary study levels is offered by only one faculty - a private Faculty of organization studies Novo mesto ("Fakulteta za organizacijske študije" - FOŠ). At the University of Ljubljana there are QM courses offered on all three levels in the programme "Strojništvo" ("Mechanical Engineering") at the Faculty of Mechanical Engineering and a QM course offered on the master programme "Poslovodenje in organizacija" ("Management and organization") at the Faculty of Economics. A few other QM courses are offered on some levels at two faculties of University of Maribor and at one private faculty. Unlike Poland [69] no special courses were recognized to be offered in cooperation with certification bodies for certifying quality managers, quality representatives and /or auditors of different management system standards (e.g. ISO 9001). Probably there still exist some other faculty courses / learning units dealing also with QM issues that we haven't found through this review of the top level structure of study programmes (see explanation for this research limitation in the last paragraph of this chapter). We believe it wouldn't change the general picture of low emphasis on QM topics in higher education.

Our business needs skilled people - not only skilled in their narrow profession, IT and languages but also understanding basic QM principles and approaches. This is one of the pillars of making improvements and driving innovation and competitiveness which are the highlighted national and European business objectives [2, 25, 34-36].

So, teaching for quality is in the business, national and international interest. Organizations (enterprises and public organizations) would benefit from it in the following ways:

- Young professionals (especially higher educated) would bring at least a basic level of QM knowledge from the school, already:

- People should know basic QM system directives and requirements (e.g. ISO 9001). They form a frame of a common understood basic order and rules of normal operation and business relations. This would contribute to better quality importance awareness and to improvement of organizational culture (more quality oriented) [41].

- QM knowledge would facilitate better decision making and more effective operation:

- Organizational knowledge, wide understanding of basic QM approaches and some basic technical and statistical skills facilitate better decision-making and managing organization's operation [21]. It is important for effective and efficient operation of the organization that as many workers as possible have at least basic understanding of the organization's QM policy and approaches. This is hard to attain and might be quite an investment if the employees didn't bring at least the basic QM knowledge and feeling from the school.

- Studying QM issues and learning QM approaches would stimulate students to search for improvements and to carry them out in an effective way: 
- PDCA cycle (Plan-Do-Check-Act) is a basic systematic improvement approach that needs to be built-in in everyone's thinking [41].

- The issue and costs of hiring external professionals would decrease:

- Organizations, especially smaller ones, often hire external QM professionals for implementation of QM projects and keep them on the contract agreements until such projects live. The related high costs of the professionals (consultants, assessors, auditors) might be quite a considerable obstacle to implementation of additional QM approaches. It has been already recognised from professional organizations (e.g. SIST, 2014) that QM costs are a real issue in micro, small and medium-sized enterprises (SMEs $=$ micro, small and medium-sized enterprises). In Slovenia, SMEs are actively involved in standardization activities; however they can't afford such costs of providing QM knowledge (materials and training) as large organizations. According to the classification made by the EU, $99.7 \%$ of all Slovenian companies belong to this group (in EU $95 \%$ of enterprises are SMEs). The Slovenian institute for standardization - SIST as the national standard publisher established a special committee for SMEs in order to better cover their interests. They prepare special offers for this group of enterprises to help them share the QM knowledge at more acceptable price [42].

As it is evident from the results of our analysis of QM related student final papers in the period of 2006 to 2013 at the faculties offering QM related programmes in the largest Slovenian university (University of Ljubljana), the amount of QM related final student papers doesn't prove high student motivation in this field of research.

In the analysed period the average percentage of the published QM related papers in the Faculty of Mechanical Engineering as a whole was $5 \%$ (that is 2 per-cent points over the average in the Faculty of economics resulting in 3\% of QM related papers among published student final papers). When comparing the shares of published QM related papers only from the QM related programmes, both institutions showed equal results: $5 \%$ of the published final student papers in the period 2006 to 2013 addressed QM issues.

The number of graduates of the analysed QM related programmes in the analysed period represented on average $20 \%$ of the graduates of all faculties and programmes at University of Ljubljana. At that time University of Ljubljana had on average $35.7 \%$ of all the graduates (on all the levels) of all higher level institutions in Slovenia, both analysed had a share of $7.2 \%$ graduates on the Slovenian level. Furthermore, the share of published QM related final student papers which is on average 3\% on the Faculty of economics and $5 \%$ on the Faculty of Mechanical Engineering represents $0,7 \%$ of the graduates of the University of Ljubljana and $0,2 \%$ of the graduates in Slovenia in the analysed period.
Such a result doesn't show much student interest and motivation for exploring QM matters. Additionally a question rises, how many students know anything about quality and quality management. In the next step another question opens: "How will these graduates treat quality and QM in their future professional life if they didn't get basic knowledge about it at school?"

The research had some limitations that should be considered when evaluating the results:

- The source of data was only publicly available data.

- Going deeper with the research and searching for quality related contents within each school programme would be the right way to come to more precise and complete answer about the share of the topics related with QM issues in the offered school programmes. We believe that some specific quality related contents might and should be added to different not QM specific courses. Analysing course lists within the school programmes and the syllabuses of adequate courses would be needed. This would be quite extensive and time consuming analysis because a great deal of all the offered courses should be examined. The number of programmes that should be examined is really high (e.g. only in the tertiary schools there were 937 study programmes in Slovenia in 2014 and each study programme had more than 10 courses [61]). Additionally, the course lists and the course syllabuses aren't generally publicly available (similarly as claimed in Bosnia and Herzegovina [68] where the investigation went deeper in the syllabuses of the courses where they were available). Therefore, the investigation of the syllabuses was not included in this preliminary research yet and could be the next and more comprehensive step of the investigation.

- The analysis of QM related student final papers was limited to only one Slovenian university (the biggest one). The QM related student final paper data were collected through electronic library system [44]. Most of the student final papers were available there. However, quite a big portion of them were not catalogued, so they couldn't be included in the analysis. During the analysis we encountered a problem of choosing the right catalogue. It was simple with the Faculty of economics which was publishing the theses of their students in its library catalogue [65]. On the contrary, the Faculty of Mechanical Engineering had their students' theses available only through the common library database [66], where it was difficult to select only the theses of that faculty. So, if there was no indication that a found QM related thesis from the field of "mechanical engineering" belonged to some other faculty, we took it as belonging to the Faculty of Mechanical Engineering of University of Ljubljana. Consequently it might appear that the number of QM 
related theses at that faculty was even lower than presented in our paper.

Teaching for quality and quality way of teaching is one of actual topics in high education and deserves deeper research. Some similar research was prepared in other EU countries under EU Tempus project, starting in 2013 [68, 69] showing different intensity and approaches in delivering QM related topics. Some continuing activities resulting in ESG quality standards in higher education (EIQAS EU Erasmus ${ }^{+}$project 2014-2016 [47]) are already in action. So a stronger background for making further research and benchmarks is being set, hopefully leading to proper improvement actions.

\section{Conclusions}

The paper gives some insight in the situation of business needs, offered teaching and students' motivation for quality in the regular Slovenian educational programmes at all the levels.

We indicated strong needs for QM knowledge - not only as adults learning initiated and financed by business organizations but also as a basic knowledge transfer through the obligatory education of youths. Such needs are also recognised from the national and European policy and action documents.

We analysed the situation in Slovenia by searching for QM regulation requirements and QM related programmes and approaches in our primary, secondary and tertiary school programmes. We found a gap between the business needs and the programmes offered. The requirements for development QM systems, learning and practicing QM in the schools are low or even not explicitly set in the regulation for general primary and secondary schools. Some QM requirements for the institutions are set and some QM related topics are offered within the courses in the professional secondary schools, but they are still rare. On the tertiary level only one complete $\mathrm{QM}$ related special study programme exists on all three levels of study at one private high education institution. Also the offer of other QM related programmes and courses is rare.

There is still a more concerning gap between students attending QM courses and the ones addressing QM issues in their final student papers. At the Faculty of economics where such a QM course is available on a master level only $5 \%$ of the published master theses or $3.3 \%$ of all the published theses were QM related. The share of QM related theses (5\%) was similar at the Faculty of Mechanical Engineering where at least one QM related course is available on all three levels. This way we found less than $1 \%$ of the graduates of University of Ljubljana that had demonstrated their interest in QM through exploration of a QM issue in their final theses.

The reason for low interest and consequently percentage of QM related final student papers may lie in low opportunities to study it as a part of some other professional programme. At the University of Ljubljana there is no special QM dedicated programmes. However, we found just two among the 26 members (academies and faculties) of this university offering QM related courses within other programmes. Probably, there exist some QM related research, student work and final papers (theses) on some other faculties. However, we couldn't see it in this preliminary research where the study programmes were not analysed in detail and local library catalogues of other faculties were not searched for the QM related student papers. Although the real situation about students' involvement in QM related research might be better than resulting from this research, it still can't satisfy the business needs on coping with the QM based mechanisms that drive better performance, such as the process management and systematic continuous improvement.

The purpose of this paper is only to highlight the issue of teaching for quality in our regular education programmes and point to the students' motivation or professional orientation in QM - just to become aware of it and to find some improvement opportunities. There should be still some more detailed research on this topic on national and international level to give stronger suggestions.

\section{REFERENCES}

[1] J. Anttila. Effective quality communication, 6th World Congress for Total Quality Management in St. Petersburg, Russia in June 2001, online available from: http://www.qualityintegration.biz/Communication.html.

[2] EC. Europe 2020: Europe's growth strategy. European Commission, 2010, online available from: http://ec.europa.e u/europe2020/europe-2020-in-a-nutshell/index_en.htm.

[3] EC. An Agenda for new skills and jobs: A European contribution towards full employment. European Commission, 2010, online available from: http://eur-lex.euro pa.eu/legal-content/EN/ALL/?uri=CELEX:52010DC0682.

[4] ISO. The ISO survey 2012. online available from: http://www.iso.org/iso/home/standards/certification/iso-surv ey.htm.

[5] M. Alic. Impact of ISO 9001 certification cancellation on business performance: a case study in Slovenian organisations. Total Quality Management \& Business Excellence, Vol. 25 No. 7-8, 790-811, 2014.

[6] P. Sampaio, P. Saraiva \& A.G.Rodrigues. ISO 9001 certification research: questions, answers and approaches. International Journal of Quality \& Reliability Management, Vol. 26 No. 1, 38-58, 2009.

[7] O. Boiral. ISO 9000 and organizational effectiveness: A systematic review. The quality management journal, Vol. 19 No. 3, 16-37, 2012.

[8] S. Dahlgaard-Park, C. Chen, I. Jang, \& J. J. Dahlgaard. Diagnosing and prognosticating the quality movement - a review on the 25 years quality literature (1987-2011). Total 
Quality Management \& Business Excellence, Vol. 24 No. 1-2, $1-18,2013$.

[9] E.L. Psomas \& C.V. Fotopoulos. A meta analysis of ISO 9001:2000 research - findings and future research proposals. International Journal of Quality and Service Sciences, Vol. 1 No. 2, 128-144, 2009.

[10] T.Van der Wiele, J.Van Iwaarden, R.Williams \& B. Dale. Perceptions about the ISO 9000 (2000) quality system standard revision and its value: the Dutch experience. International Journal of Quality \& Reliability Management, Vol. 22 No. 2, 101-119, 2005.

[11] H.A.E. Magd. ISO 9001:2000 in the Egyptian manufacturing sector: perceptions and perspectives. International Journal of Quality \& Reliability Management, Vol. 25 No. 2, 173-200, 2008.

[12] B. Rusjan, M. Alič. Capitalising on ISO 9001 benefits for strategic results. International Journal of Quality \& Reliability Management, Vol. 27 No. 7, 756-778, 2010.

[13] D. Solomon, O.Hogan. The contribution of quality management to the UK economy. London, UK: Centre for Economics and Business Research, 2012, online available from: http://www.managers.org.uk/quality-management.

[14] M.Bangert. Make ISO work for you. BNP Media, Vol. 2012 No. June, 30-35, 2012.

[15] E. Dimara et al.. Strategic orientation and financial performance of firms implementing ISO 9000. International Journal of Quality \& Reliability Management, Vol. 21 No. 1, 72-89, 2014.

[16] S. Mathews. ISO 9000 survey shows value of customer focus and gives purchaser's viewpoint. ISO Management Systems, Vol. 2005 No. Sept.-Oct., 15-19, 2005.

[17] L. Boulter et al.. Report on EFQM and BQF funded study into the impact of the effective implementation of organizational excellence strategies on key performance results. UK: The Centre of Quality Excellence, University of Leicester, 2006.

[18] J.Singels, G.Ruel, H. Van de Water. ISO 9000 series Certification and performance. International Journal of Quality \& Reliability Management, Vol. 18 No. 1, 62, 2001.

[19] C. Chow-Chua, M. Goh, T. B. Wan. Does ISO 9000 certification improve business performance?. International Journal of Quality \& Reliability Management, Vol. 20 No. 8/9, 936-953, 2003.

[20] M. Martinez-Costa, A. R. Martinez-Lorente. A triple analysis of ISO 9000 effects on company performance. International Journal of Productivity \& Performance Management, Vol. 56 No. 5/6, 484-499, 2007.

[21] J. Llopis, J. J. Tari. The importance of internal aspects in quality improvement. The International Journal of Quality \& Reliability Management, Vol. 20 No. 2/3, 304-324, 2003.

[22] D. I. Prajogo. The roles of firms' motives in affecting the outcomes of ISO 9000 adoption, International Journal of Operations \& Production Management, Vol. 31 No. 1, 78-100, 2011.

[23] MGRT. Program celovitega spodbujanja kakovosti v turizmu (Programme of promoting total quality in turism). Ministrstvo za gospodarski razvoj in tehnologijo - MGRT (Ministry of economic development and technology), 2006, online available from: http://www.mgrt.gov.si/fileadmin/mgrt.gov.s i/pageuploads/turizem/MG-Program_celovitega_spodbujanja kakovosti.pdf.

[24] GZS. Agenda 48+. Ljubljana : Gospodarska zbornica Slovenije - GZS (Slovenian Chamber of Commerce), April $16^{\text {th }}, 2013$, online available from: http://www.gzs.si/slo/skup ne_naloge/za_uspesno_slovenijo/59870 (accessed April $29^{\text {th }}$, 2014).

[25] MGRT. Slovenska industrijska politika 2014-2020 - SIP (Slovenian industrial policy). Ministrstvo za gospodarski razvoj in tehnologijo - MGRT (Ministry of economic development and technology), 2013, online available from: http://www.mgrt.gov.si/fileadmin/mgrt.gov.si/pageuploads/ DPK/SIP/SIP___vladni_dokument.pdf.

[26] GZS. Prispevek Gospodarske zbornice Slovenije k osnutku Strategije pametne specializacije 2014-2020 (Contribution of The Slovenian Chamber of Commerce to the draft paper of Strategy of clever specialisation 2014-2020). Ljubljana : Gospodarska zbornica Slovenije - GZS (Slovenian Chamber of Commerce), July $30^{\text {th }}, 2013$, online available from: http://www.gzs.si/slo/skupne_naloge/za_uspesno_slovenijo/ 59870.

[27] P. Kovač, B. Grošelj. Odličnost v slovenski javni upravi 1995-2006. (Excellence in Slovenian public administration 1995-2006), Nacionalna meroslovna institucija - MIRS (National Metrology Institution), 2007, online available from: http://www.mirs.gov.si/fileadmin/um.gov.si/pageuploads/Do kpdf/PRSPO/LiteraturaSlo/brosura_JU_SLO_tisk.pdf.

[28] UJP. Politika kakovosti Uprave za javna plačila RS - UJP (Quality policy of Public payments administration of Republic Slovenia), 2011, online available from: http://www.ujp.gov.si/dokumenti/dokument.asp?id=346.

[29] G.Virant. Usmerjenost javne uprave $\mathrm{k}$ uporabniku (Customer-oriented public adminstration), 2012, online available from: http://www.mpju.gov.si/fileadmin/mpju.gov. si/pageuploads/Kakovost/Zbornik_2002.pdf.

[30] B. Simčič et al.. Nacionalna strategija kakovosti in varnosti v zdravstvu $(2010$ - 2015) (National strategy of qulity and safety in health care (2010-2015)). Ljubljana: Ministry of health, 2010, online available from t: http://www.mz.gov.si/f ileadmin/mz.gov.si/pageuploads/kakovost/nacionalna_strate gija_kakov_in_varn_2010-2015/Nacionalna_strategija_kako vosti in varnosti v zdravstvu 2010-2015.pdf.

[31] SZKO. Priporočilo AUKN - Doseganje kakovosti in odličnosti poslovanja družb/skupin (Recommendation of AUKN Attaining quality and business excellence of companies/groups). Slovensko združenje za kakovost in odličnost - SZKO (Slovenian Association for Quality and Excellence), Jan. 19 ${ }^{\text {th }}$, 2013, online available from: http://www.szko.si/novice/6/.

[32] SOD. Priporočila upravljavca posrednih in neposrednih kapitalskih naložb Republike Slovenije (Recommendations of the governer of indirect and direct capital investments in Republic Slovenia). Ljubljana : Slovenska odškodninska družba - SOD, Mar. 2013, online available from: http://www.zdruzenje-ns.si/db/doc/upl/priporocila_upravljav ca posrednih in neposrednih kapitalskih nalozb rs.pdf.

[33] RS. Actual problems in the health area - public hearings. transcripted voice records of the meeting on Jan. $23^{\text {th }}, 2014$, Ljubljana : The Republic of Slovenia - RS, National Assembly - Board on Health. 
[34] EC. An Integrated Industrial Policy for the Globalisation Era. European Commission, 2010, online available from: $\mathrm{http} / /$ ec.europa.eu/enterprise/policies/industrial-competitive ness/industrial-policy/files/communication_on_industrial_po licy_en.pdf.

[35] EC. Enterprise and industry - key challenges. European Commission, 2010, online available from: http://ec.europa.e $\mathrm{u} /$ enterprise/policies/industrial-competitiveness/industrial-po licy/key-challenges/index_en.htm.

[36] EC. Competition - Making markets work better - European competition policy. European Commission, 2010, online available from:http://europa.eu/pol/pdf/flipbook/en/competit ion_en.pdf.

[37] EUROCHAMBRES. SMEs and innovation, The Association of European Chambers of Commerce and Industry, 2013, online available from: http://www.eurochambres.eu/Content/ default.asp?pagename $=$ SMEsAndInnovation .

[38] EFQM (2012). The EFQM excellence model. EFQM, 2012, online available from: http://www.efqm.org/the-efqm-excell ence-model.

[39] T. Van der Wiele, A. Brown. Quality management over a decade. International Journal of Quality \& Reliability Management, Vol. 19 No. 5, 508-523, 2002.

[40] W.Wanderbrande. The quality manager of the future: beauty or the beast?. $22^{\text {th }}$ annual conference of SZKO - Nov. 14-15 $5^{\text {th }}$, 2013. Portorož : Slovensko združenje za kakovost in odličnost - SZKO (Slovenian Association for Quality and Excellence), available at: http://www.szko.si/uploads/files/S ZKO-Zbornik-22-povzetki.pdf.

[41] J.Disney, H.Crabtree, P. Harrison. The case for undergraduate education in quality management. Total Quality Management, Vol. 11 No. 4-6, 574-580, 2000.

[42] SIST. Paying more attention to micro, small and medium-sized enterprises (MSMEs). Slovenski inštitut za standardizacijo - SIST (Slovenian institute for standardization), 2014, available at: http://www.sist.si/index. php?option $=$ com_content\&view $=$ article $\&$ id $=280 \&$ Itemid $=2$ 09\&lang=en.

[43] MIZS. Regulation and public data on primary, secondary and tertiary education. Ministrstvo za izobraževanje, znanost in sport - MIZS (Ministry of education, science and sport), online available from: http://www.mizs.gov.si/si/zakonodaja in_dokumenti/veljavni_predpisi_s_podrocja_izobrazevanja/

[44] COBISS. Co-operative Online Bibliographic System and Services, COBISS/OPAC, online available from: http://cobiss5.izum.si/scripts/cobiss?ukaz=BMEN\&id=0047 292450018816

[45] SURS. Izobraževanje v Sloveniji (Education in Slovenia). note on April $24^{\text {th }}, 2012$, online available from: http://www.stat.s i/novica_prikazi.aspx $? \mathrm{id}=4650$.

[46] NAKVIS. Criteria for the accreditation and external evaluation of higher education institutions and study programmes, 2014, online available from: http://test.nakvis.s i/sl-SI/Content/Details/5.

[47] ENQA. ESG 2015 - Standards and Guidelines for Quality Assurance in the European Higher Education Area .European Association for Quality Assurance in Higher Education, 2015, online available from:http://www.enqa.eu/index.php/home/e $\mathrm{sg} /$.

[48] Murski val. Osnovni šoli II podelili certifikat ISO 9001, 2008, online available from: http://www.siq.si/fileadmin/siqnew/iz o/KzP/RA_MURSKI_VAL_O_II_podelili_certifikat_ISO -9001_22_april_2008.pdf.

[49] SIQ. Vzpostavljanje sistema vodenja kakovosti po modelu $\mathrm{KzP}$ (Implementing KzP QM system). Slovenian Institute for Quality and Metrology - SIQ, 2014, online available from: http://www.siq.si/solstvo/.

[50] SIQ. Letak KzP (Flyer KzP). Slovenian Institute for Quality and Metrology - SIQ, 2014, online available from: http://www.siq.si/index.php?eID=tx_nawsecuredl\&u=0\&file $=$ fileadmin/siqnew/izo/KzP/KZP.pdf\&t=1404425699\&hash $=e 21 \mathrm{~d} 4 \mathrm{a} 771 \mathrm{be} 4596640789 \mathrm{baa} 16 \mathrm{~b} 35 \mathrm{e} 51248 \mathrm{~b} 52 \mathrm{~b} 3$.

[51] S. Zajec. Prenos dobrih praks managementa kakovosti v visokem šolstvu : primer Ekonomske fakultete Univerze $\mathrm{v}$ Ljubljani. magistrsko delo, Ekonomska fakulteta, Ljubljana, 2010.

[52] B. Škafar. Navodilo za vzpostavljanje in zagotavljanje sistema vodenja kakovosti $\mathrm{v}$ višjih strokovnih šolah, 2008, online available from:http://www.impletum.zavod-irc.si/docs/Skriti dokumenti/Impletum A9 Navodilo za vzpostaljanje in $\mathrm{z}$ ăgotavljanje_sistema_k̄akovosti_v_VSSS.pdf.

[53] Bukovec, B. S procesnim pristopom do izboljšanja kakovosti visokega šolstva. Dlib - Raziskave in razprave. URN:NBN:SI:DOC-BEPIFJAC, 1(3), 213-234, 2008, online available from: www.dlib.si/stream/URN:NBN:SI:DOC-BE PIFJAC/...6057.../PDF.

[54] FOŠ. Pridobitev certifikata ISO 9001. Novice FOŠ. Fakulteta za organizacijske študije, 2011, online available from: http://www.fos.unm.si/si/novice/?id=412.

[55] A. Prašnikar, K. Kern Pipan. Pristopi za spodbujanje kakovosti in odličnosti v visokem šolstvu, 2011, online available from: http://www.mirs.gov.si/fileadmin/um.gov.si/pageuploads/Do kpdf/PRSPO/Literatura/2011-Konferenca Portoroz-Prasnika r_KernPipan.pdf.

[56] OAQ. ENQA workshop on Institutional Quality Audits. Summary. Zürich: Center of accreditation and quality assurance of the Swiss universities, 1-2 December 2003, online available from:http://www.enqa.eu/files/workshop_m aterial/summary_zurich.pdf.

[57] C.-Y.Chena, P.-C. Chenb, P.-Y. Chenc. Teaching quality in higher education: An introductory review on a process-oriented teaching-quality model. Total Quality Management \& Business Excellence, Vol. 25 No. 1-2, 36-56, 2014.

[58] MIZS. Educational programmes of primary schools. Ministrstvo za izobraževanje, znanost in sport - MIZS (Ministry of education, science and sport), 2014, online available from: http://www.mizs.gov.si/si/delovna_podrocja/ direktorat za predsolsko_vzgojo_in_osnovno_solstvo/osnov no_solstvo/program/.

[59] MIZS. Educational programmes of secondary middle level schools. Ministrstvo za izobraževanje, znanost in sport MIZS (Ministry of education, science and sport), 2014, online available from: $\mathrm{http}: / / \mathrm{www} . \mathrm{mizs} . g o v . s i /$ si/delovna podrocja/ direktorat za srednje in visje solstvo ter_izobrazevanje o draslih/srednjesolsko_izobrazevanje/srednjesolski_izobrazev alni_programi/. 
[60] MIZS. Educational programmes of secondary higher level schools. Ministrstvo za izobraževanje, znanost in sport MIZS (Ministry of education, science and sport), 2014, online available from: http://www.mizs.gov.si/si/delovna_podrocja/ direktorat_za_srednje_in_visje_solstvo_ter_izobrazevanje_o draslih/visjesolsko_izobrazevanje/programi/.

[61] MIZS. Educational programmes of tertiary (higher education) schools. Ministrstvo za izobraževanje, znanost in sport MIZS (Ministry of education, science and sport), 2014, online available from: http://www.mizs.gov.si/si/delovna_podrocja/ direktorat_za_visoko_solstvo/sektor_za_visoko_solstvo/razv id visokosolskih zavodov/.

[62] CPI. Standardi poklicnih in strokovnih kvalifikacij (Secondary vocational and professional qualification standards). Center RS za poklicno izobraževanje, 2014, online available from: http://www.cpi.si/nizje-poklicno-izobrazevanje.aspx

[63] UL. University in numbers. University of Ljubljana (UL), 2014, online available from: https://www.uni-lj.si/university/ university_in_numbers/.

[64] SURS. SI-STAT podatkovni portal: podatki o diplomantih in študentih V RS (Education in Slovenia), 2013, online available from: http://www.stat.si/pxweb/Database/Dem_soc /Dem soc.asp\#09.

[65] CEKLJ. List of published student final papers from the Faculty of economics. Search results from Central economics library (CEKLJ), online available from: http://cobiss5.izum.si/script s/cobiss?ukaz=BMEN\&id=0047292450018816.

[66] COBIB. List of published student final papers from the Faculty of mechanical engineering. Search results from COBISS/OPAC - COBIB, 2014, online available from:
http://cobiss5.izum.si/scripts/cobiss?ukaz=BMEN\&id $=0047$ 292450018816.

[67] SURS. Izobraževanje v Sloveniji (Education in Slovenia). note on March $12^{\text {th }}, 2014$, online available from: http://www.stat.si/tema_demografsko_izobrazevanje.asp.

[68] S. Jašarević, S. Lemeš. QMS in higher education study programs in Bosnia and Herzegovina. EU Tempus project. 8th International Conference ICQME 2014. Tivat, Montenegro : Center for quality, 41-49, 2014, online available from:https://www.academia.edu/8456584/QMS in _higher_education_study_programs_in_Bosnia_and_Herzeg ovina

[69] P. Kafel, T. Sikora. Analysis of Training Programs In The Field Of Qms In Poland. EU Tempus project. 8th International Conference ICQME 2014. Tivat, Montenegro : Center for quality, 175-181, 2014, the report online available from http://www.eqiwbc.ac.me/download/Reports_EU/Anal ysis $\% 20$ of $\% 20$ training $\% 20$ programs $\% 20$ in $\% 20$ the $\% 20$ field $\% 20$ of $\% 20$ QMS\%20in\%20Poland.pdf

[70] MIRS. Seznam ocenjevalcev priznanja rs za poslovno odličnost (PRSPO) 2003-2014, Nacionalna meroslovna institucija - MIRS (National Metrology Institution), 2016, online available from: http://www.mirs.gov.si/si/delovna po drocja/poslovna odlicnost prspo/prspo drzavna nagrada za _odlicnost/ocenjevalna_komisija_za_priznanja_rs_za_poslo vno_odlicnost/seznam_ocenjevalcev_priznanja_rs_za_poslo vno_odlicnost_prspo/.

[71] H. Kaynak. The relationship between total quality management practices and their effects on firm performance. Journal of Operations Management, Vol. 21 No. 4, 405-435, 2003. 